1 This document is the author's post-print version of this article, i.e. the final draft version after 2 review. The final document is available in Wood Science and Technology and can be viewed 3 online by using the doi:10.1007/s00226-018-1070-6.

4 We also refer to this URL for citing details.

5 


\title{
Density and density profile changes in birch and spruce caused by thermo- hydro treatment measured by $X$-ray computed tomography
}

\author{
Vladimirs Biziks*, Joris Van Acker, Holger Militz, Juris Grinins and Jan Van den \\ Bulcke
}

*Corresponding author: Vladimirs Biziks, Georg-August University of Goettingen, Faculty of Forest Science and Forest Ecology, Department of Biology and Wood Products, Büsgenweg 4, 37077 Göttingen, Germany; vbiziks@gwdg.de

Jan Van den Bulcke: UGCT - UGent-Woodlab, Laboratory of Wood Technology, Department of Environment, Faculty of Bioscience Engineering, Ghent University, Coupure Links 653, 9000 Ghent, Belgium; UGCT, University of Ghent Center of X-ray Tomography, Proeftuinstraat 86, 9000 Gent, Belgium

Juris Grinins: Latvian State Institute of Wood Chemistry, 27 Dzerbenes str., Riga 1006, Latvia

Joris Van Acker: UGCT - UGent-Woodlab, Laboratory of Wood Technology, Department of Environment, Faculty of Bioscience Engineering, Ghent University, Coupure Links 653, 9000 Ghent, Belgium; UGCT, University of Ghent Center of X-ray Tomography, Proeftuinstraat 86, 9000 Gent, Belgium

Holger Militz: Georg-August University of Goettingen, Faculty of Forest Science and Forest Ecology, Department of Biology and Wood Products, Büsgenweg 4, 37077 Göttingen, Germany

\section{Abstract}

Birch and spruce samples were scanned using X-ray computed tomography $(\mathrm{CT})$ to determine changes in the density and density profile caused by thermo-hydro treatment (THT). Smalldimension wood blocks were subjected to treatment at three different temperatures $\left(160^{\circ} \mathrm{C}\right.$, $170^{\circ} \mathrm{C}$ and $180^{\circ} \mathrm{C}$ ) for 1 hour and scanned before and after treatment. Identical acquisition and analysis procedures were used to evaluate the changes in approximate mean density and radial density profile of oven-dried untreated and treated material. The X-ray CT scans enabled measuring of the changes in wood density after THT. The results confirm that there were similar tendencies in the total density decrease with increasing temperature. However, variations in density changes between the earlywood (EW) and latewood (LW) of birch and spruce were found. A correlation of the radial density profiles of treated versus untreated specimens showed a similar density decrease in EW and LW in birch wood and inconsistent reductions in spruce wood. 


\section{Introduction}

Wood density, a measure of the total amount of cell wall material available per volume unit, is known to influence physical, mechanical and durability properties of wood. These relationships have been well studied, with density having a positive influence on mechanical properties (bending strength, hardness, impact bending strength) and swelling behavior, and having less impact on resistance to decay (Gilmor et al. 1959; Mantanis et al. 1994; Wong et al. 1983; Guilley et al. 2004; Izekor et al. 2010).

During thermal treatment, wood cell wall components undergo chemical transformations through autocatalytic reactions induced by heat, pressure and steam (Dietrichs et al. 1978; Grinins et al. 2013), which result in the simultaneous reduction in volume (shrinkage) and cell wall matter (mass loss). These irreversible transformations alter the properties of wood, and the main drawback of the thermal treatment is the reduction in mechanical properties. The magnitude of such decreases differs from process to process; Yildiz (2006) and Boonstra et al. (2007) showed that the density of wood treated by the French method (rectified wood) between $200^{\circ} \mathrm{C}$ and $260^{\circ} \mathrm{C}$ decreased by approximately $15 \%$ for spruce wood compared to $8.5 \%$ for Norway spruce heat-treated according to the Plato process at $165^{\circ} \mathrm{C}$. Because of these disadvantages, thermally treated wood is mainly used for outdoor applications (e.g., decking, cladding, garden furniture, etc.) or in construction projects with low loading forces.

Rathgeber et al. (2006) found a high correlation between density and the earlywood (EW) and latewood (LW) proportions in the growth rings of softwoods, and they showed that from the beginning of a growth ring to the end, the wood density (WD) has an S-shaped profile, which was attributed to the cell wall proportion (CWP), or the volume of wood cell wall matter. Wood density increases primarily because of cell-wall thickening in tangential and radial directions as well as cell-size reductions in the radial direction. In 1993, Niemz published work that confirmed that the physical and mechanical properties of LW of softwood are 1.5-2 times higher than those of EW, which might be explained by intra-tree-ring wood density variations and fiber anatomical characteristics Rathgeber et al. (2006).

Hence, it is crucial to accurately evaluate changes in the density and density profile within a growth ring of wood caused by heat treatments to better understand the behavior of wood that is subjected to different treatment temperatures. Because the proportion of wood 
cell wall matter in LW plays such a significant role in the mechanical properties, it is important to assess whether the LW and EW show a similar or different decrease in density.

Pfriem et al. (2014) and Clauder et al. (2014) performed initial evaluations of the influence of treatment temperature on changes in density within a growth ring using a highfrequency densitometer. They found that as the treatment temperature increased, the EW experienced a decrease in density that was 2- to 3 -fold larger than in the $\mathrm{LW}$ treated at $220^{\circ} \mathrm{C}$. However, the authors indicated that the measurement accuracy required improvement because differences of approximately $18 \%$ were observed between the high-frequency and gravimetric methods. Similar findings were found by Hamada et al. (2017). They evaluated the thermal stability of earlywood (EW) and latewood (LW) in heartwood (HW) and sapwood (SP) growth rings of European oak tree in terms of mass losses. They found that EW had around $12 \%$ more mass losses compared to LW and explained this difference in mass loss by the higher ratio of cellulose in LW due to the thicker secondary cell wall layer. Other advanced techniques have been successfully demonstrated that could efficiently reveal the density distribution in wood. X-ray computed tomography (CT) is able to evaluate the density of different types of materials, including wood and wood products (Mull 1984; Lindgren 1991; Freyburger et al. 2009), and identify changes in the density and density profile after different treatments, such as the surface densification of wood (Rautkari et al. 2010) after treatment with thermosetting resins (Klüppel and Mai 2013). Additionally, Meincken and du Plessis (2013) were among the first to report changes in the density of degraded wood caused by different temperatures by using X-ray CT.

The aim of this study was to assess changes in the density profile and density of wood after thermo-hydro treatment (THT) using different treatment temperatures. To determine the accuracy of the X-ray CT method, the density values obtained by X-ray CT were compared with gravimetrically measured density. Then, changes in the density profile of birch and spruce wood treated with THT at three different temperatures were determined.

\section{Materials and methods}

\section{Sample description}

Silver birch (Betula pendula) and Norway spruce (Picea abies) were used to assess the impact of THT temperature on wood density WD and the radial density profile. Two groups of samples were prepared, with the first group tested using gravimetric measurements and the 
second group tested with X-ray CT (Figure 1). To increase the accuracy of the tests, the same specimen was scanned before and after treatment. The wood blocks were oven-dried and stored in a desiccator to achieve identical conditions prior to scanning. Prior to the treatments, all the specimens were placed in a sample holder and scanned. After scanning of the untreated samples, each group of specimens was subjected to the THT at $160^{\circ} \mathrm{C}, 170^{\circ} \mathrm{C}$ and $180^{\circ} \mathrm{C}$.

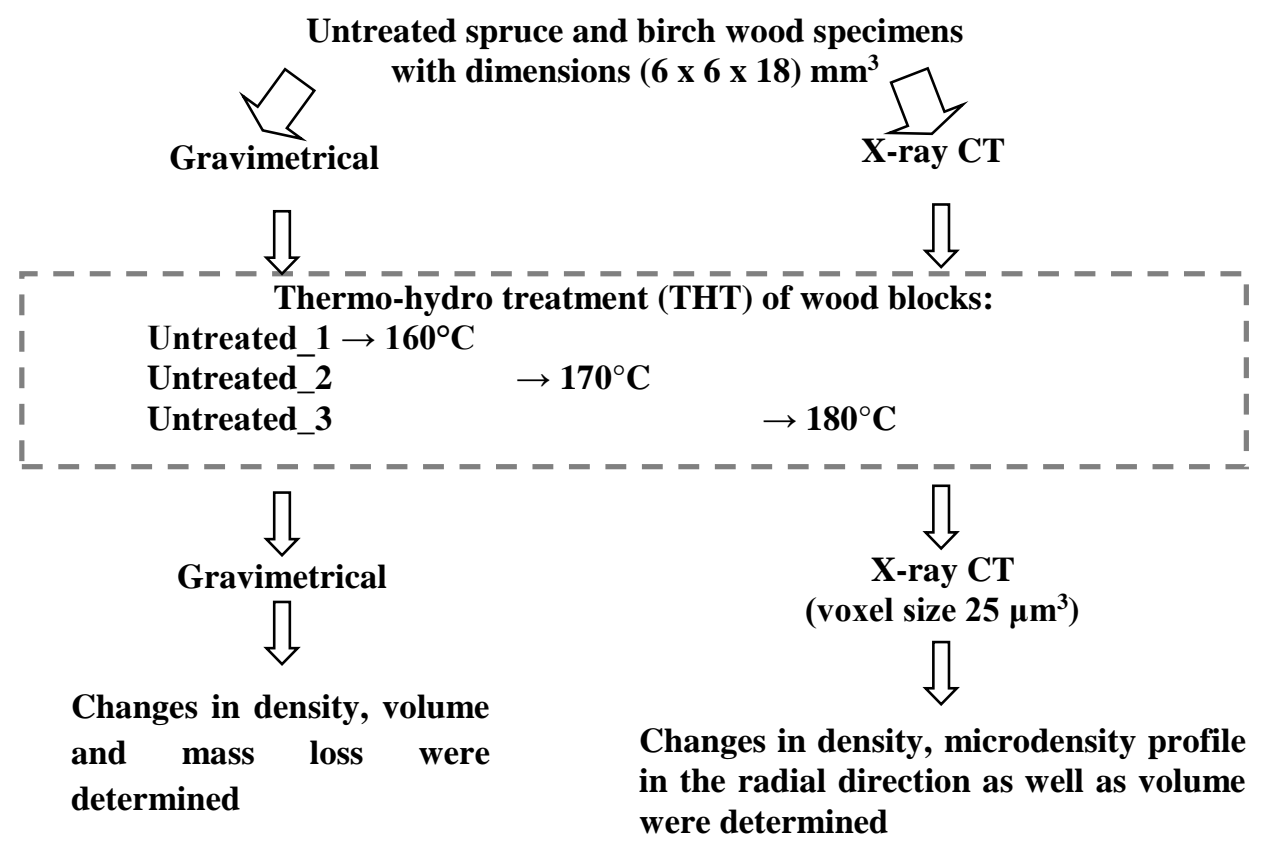

Figure 1. Flowchart of gravimetrical measurements and X-ray CT for estimating the changes in density and density profiles of wood samples before and after THT.

Additionally, high-resolution X-ray CT scans were made to clearly illustrate shrinkage of the wood tissue after THT.

\section{Treatment}

The THT treatments were conducted in a pilot-scale 560L stainless steel autoclave produced by WTT, Denmark, and all treatment steps were performed according to the procedure described in Biziks et al. (2015). The mass loss (ML) of the THT specimens was calculated as $m_{T}(\%)=100\left(m_{0}-m_{1}\right) / m_{0}$ (Eq. 1$)$, where $m_{T}$ is the ML caused by the THT, and $m_{0}$ and $m_{1}$ are the oven-dried masses of the specimens before and after THT, respectively. One sample per treatment was used during the measurement.

\section{Gravimetrical method}


Gravimetric density is defined as the oven-dried weight over the oven-dried volume of the specimen. The weight of the oven-dried specimens was determined with a laboratory balance (precision of $0.0001 \mathrm{~g}$ ), and the volumes were obtained manually with calipers and by image processing on the reconstructed X-ray CT volumes. The changes in density after THT were calculated according to (Eq. x) $\left.\Delta \rho(\%)=\left(\left(\rho_{\text {utr }}-\rho_{\text {tr }}\right) / \rho_{\text {utr }}\right)\right)$ x $100 ; \rho_{\text {utr }}=\left(\left(m_{\text {dry }} / V_{\text {dry }}\right)_{\text {utr }}(\right.$ Eq. $\mathrm{x})$ and $\rho_{\mathrm{tr}}=\left(\left(m_{\mathrm{dry}} / V_{\mathrm{dry}}\right)_{\text {tr }}(\right.$ Eq. $\mathrm{x})$, where $\rho_{\text {utr }}$ is the density of untreated specimen, $\rho_{\mathrm{tr}}$ is the density of specimen after THT, $m_{\text {dry }}$ is oven-dry mass of the specimens, $V_{\text {dry }}$ is oven-dry volume of the specimens.

$X$-ray CT scanning for density measurements

Oven-dried untreated and THT-treated specimens were subjected to identical acquisition and analysis procedures. All of the specimens were scanned using the Nanowood scanner at the Center for X-ray Tomography at Ghent University (UGCT; http://www.ugct.ugent.be). Details of the scanner can be found in Dierick et al. (2014). This flexible, state-of-the-art scanner is controlled using in-house developed software with a generic interface (Dierick et al. 2010). The samples were mounted in a dedicated sample holder and scanned using a helical trajectory. The data were reconstructed with the Octopus software package (Vlassenbroeck et al. 2007), a tomography reconstruction package for parallel, cone-beam and helical geometry. The scans had an approximate voxel pitch of 25 $\mu \mathrm{m}$. The reconstructed images of the samples before and after THT were visualized using the Octopus Analysis package (www.xre.be, previously known as Morpho+ (Brabant et al. 2011). Conversion of grayscale values to actual densities was done according to the procedure described in De Ridder et al. (2011).

\section{High resolution $X$-ray CT scanning}

Birch and spruce wood samples were prepared from larger blocks and subdivided using a scalpel into needle-shaped specimens measuring approximately 0.4 x 0.4 x $6 \mathrm{~mm}^{3}$. Specimens were oven-dried and stored in a desiccator to avoid volume fluctuations caused by moisture absorption. The same specimens were scanned before and after the THT regime at $160^{\circ} \mathrm{C}$. All wood pieces were scanned at an average voltage of $55 \mathrm{kV}$, a target current of 160 $\mu \mathrm{A}$, and an exposure time of $1500 \mathrm{~ms}$ per image, resulting in an approximate scan time of $45-$ 
15360 min per object. Reconstruction was also performed with Octopus, with ca. 20 min per scan.

154 All specimens were filtered by the phase contrast method in Octopus (De Witte et al. 2009; 155 Boone et al. 2009). The resulting high-resolution scans had an approximate voxel pitch of $156 \quad 0.8-1.2 \mu \mathrm{m}$ (some samples were scanned at $0.8 \mu \mathrm{m}$ resolution, others at $1.2 \mu \mathrm{m}$ ) with $2^{16}$ 157 grayscale levels, which were used to obtain high-resolution 3D images. Reconstructed images 158 of the samples before and after THT were visualized by Octopus Analysis (www.xre.be; 159 previously known as Morpho+; Brabant et al. 2011) and rendered 3D images by means of 160 VGStudio MAX. A 3D rendering of the X-ray volumes of specimens before and after 161 treatment was produced, to illustrate the alteration of microstructure of wood caused by THT 162 (shrinkage).

\section{Results}

\section{Gravimetric method versus X-ray CT method}

The densities were calculated from the manually measured mass and volume measured by X-ray CT and compared to the mean densities obtained by X-ray CT. A linear relationship was observed for the untreated and treated samples between the two measurements of wood density (WD) with a correlation coefficient of 0.943 , which demonstrated the accuracy of the X-ray CT measurements (Figure 2). The densities calculated from X-ray scans overestimated the gravimetric density by $4 \%$ and $0.5 \%$ on average for untreated and treated samples, respectively. This increase in results can be explained by the more precise identification of the volume by X-ray CT compared to manually taken measurements. During the measurements with caliper, the surface roughness of the sample is not taken into considerations, therefore, in such a way, higher values in volume is achieved, which leads to decreases in density detected by gravimetrical method, which is more correct than the manual measurements. 


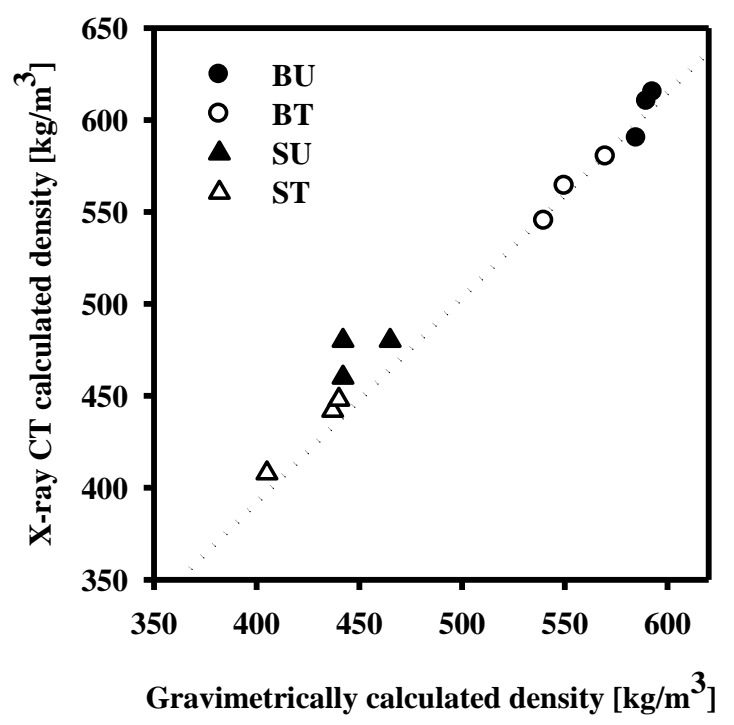

Figure 2. Relationship between densities measured with X-ray CT and gravimetric analyses. BU and SU - birch and spruce before the thermal treatment; BT and ST -birch and spruce after thermal treatment.

The impact of treatment temperature on the density of birch and spruce is shown in

Figure 3. After treatment at $160^{\circ} \mathrm{C}$, the $\mathrm{ML}$ of birch wood was approximately $30 \%$ higher than that of spruce. Nevertheless, the spruce samples presented a significantly higher decrease

187 in density (nearly 1.5 times) compared with birch wood, which can be explained by 188 differences between wood species with respect to their different shrinkage. The ML and 189 decreased volume and density of birch and spruce blocks caused by various treatment 190 temperatures are listed in Table 1 . The decrease in density at $170^{\circ} \mathrm{C}$ was approximately $1.5-3$ 191 times larger than that after treatment at $160^{\circ} \mathrm{C}$. Regardless of the wood species, wood samples 192 that were subjected to the highest temperature $\left(180^{\circ} \mathrm{C}\right)$ achieved the largest decrease in 193 density. 


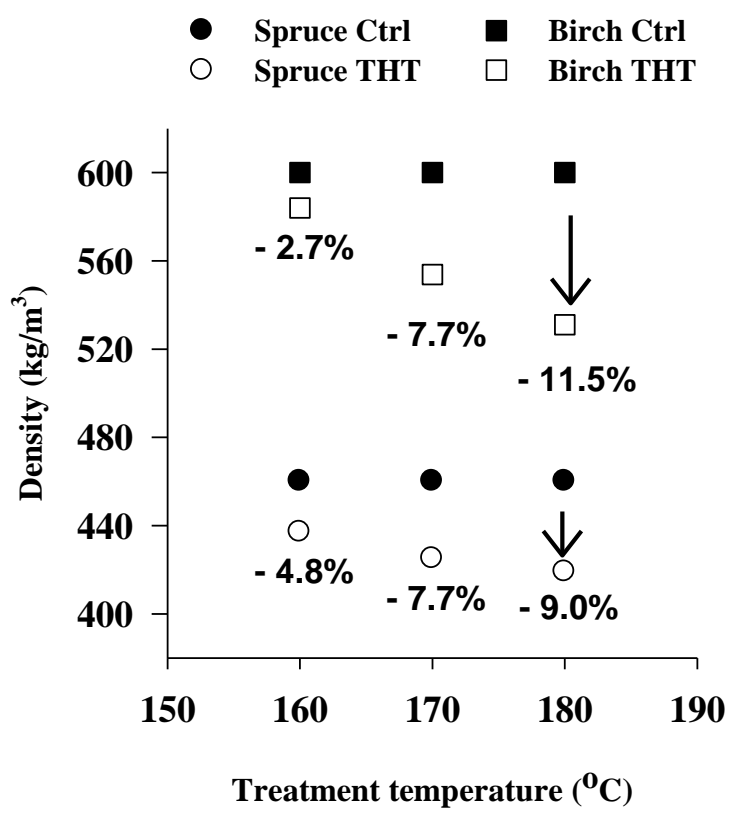

Figure 3. Relationship between reduction in density of birch and spruce woods caused by different treatment temperatures - determined gravimetrically.

The results obtained from both measurement methods (gravimetric and X-ray CT) clearly confirm that increases in treatment temperature lead to decreases in density because of the greater mass loss relative to the shrinkage. However, density changes after treatment were different between the wood species; at $160^{\circ} \mathrm{C}$, birch showed a lower density change than spruce $\left(-2.7 \%\right.$ against $4.8 \%$ respectively), while at $170^{\circ} \mathrm{C}$, the changes in the two species are the same and at $180^{\circ} \mathrm{C}$, birch showed higher density change than spruce $(-11.5 \%$ against $9.0 \%$ respectively). The magnitude and physical reasons of the decrease in density can be explained by the different chemical composition and amount of wood components within the cell wall. According to Altgen et al. (2016), the majority of native extractives are removed from wood at comparably low treatment temperature ranges, between 100 and $140{ }^{\circ} \mathrm{C}$, when performing the thermal modification process at elevated pressure. This causes a loss in dry wood mass, even if no degradation of cell wall constituents takes place. The higher decreases in density of spruce compared to birch at an early stage of treatment $\left(<160{ }^{\circ} \mathrm{C}\right)$ might be explained by the fact that spruce contains more extractives and less hemicelluloses compared to birch, which resulted in higher mass loss but lower shrinkage compared to birch. With increasing modification temperature above $160{ }^{\circ} \mathrm{C}$, hemicelluloses and amorphous parts of the cellulose are also affected by the more severe thermal decomposition in the cell wall, which afterwards leads to cell wall shrinkage. Birch contains more hemicelluloses (less thermally stable component in the cell wall) compared to spruce (Gonzalez et al. 2009) and, therefore, it 
might be reasonable that spruce showed a lower decrease in density compared to birch at a treatment temperature of $180{ }^{\circ} \mathrm{C}$.

Table 1. Relationship between the decrease in density of birch and spruce caused by different treatment temperatures and estimated by both gravimetric analysis and X-ray CT

\begin{tabular}{ccccccc}
\hline \multirow{2}{*}{ Wood species } & $\begin{array}{c}\text { Treatment } \\
\text { temperature } \\
\left({ }^{\circ} \mathbf{C}\right)\end{array}$ & $\begin{array}{c}\text { Mass loss } \\
(\boldsymbol{\%})\end{array}$ & \multicolumn{2}{c}{$\begin{array}{c}\text { Decrease in volume } \\
(\boldsymbol{\%})\end{array}$} & \multicolumn{2}{c}{$\begin{array}{c}\text { Decrease in density } \\
(\boldsymbol{\%})\end{array}$} \\
\cline { 4 - 7 } & & & Caliper & X-ray CT & Gravimetrical & X-ray CT \\
\hline \multirow{3}{*}{ Spruce } & 160 & 4.2 & 0.4 & 1.8 & 3.8 & 4.8 \\
& 170 & 7.9 & 0.4 & 1.6 & 7.5 & 7.7 \\
& 180 & 11.0 & 3.3 & 5.2 & 8.0 & 9.0 \\
\multirow{2}{*}{ Birch } & 160 & 5.8 & 5.5 & 3.7 & 0.4 & 2.7 \\
& 170 & 13.3 & 7.8 & 7.5 & 5.9 & 7.7 \\
& 180 & 18.4 & 9.9 & 11.0 & 9.4 & 11.5 \\
\hline
\end{tabular}

221

\section{Density profile of untreated samples}

The density profile along the radial direction of a given sub-volume was compared before and after THT. In Figure 4, the black curves correspond to density profiles of the region of interest (ROI $-4 \times 5 \times 20 \mathrm{~mm}^{3}-\mathrm{R} \times \mathrm{Tg} \times \mathrm{L}$ directions, respectively) in the untreated wood. The data shows that the WD varied from 250 to $1010 \mathrm{~kg} / \mathrm{m}^{3}$ for spruce and from 440 to $790 \mathrm{~kg} / \mathrm{m}^{3}$ for birch within the same annual ring. Steffenrem et al. (2014) confirmed that the precise minimum and maximum values are more affected by the treatment of wood with narrow growth rings. Similarly, precise estimation of the minimum and maximum values in the radial density profile could be influenced by large differences in density between EW and LW, the presence of sharp borders between EW and LW, displacement (deflection, flouting) of growth rings along the longitudinal direction, as well as scanning resolution.

The graphs in Figure $4 \mathrm{a}$ and $4 \mathrm{~d}$ show rather distinct profiles between both wood species, due to different porosities, which indicates a non-equal distribution of wood cell wall matter within the same growth ring closely associated with distinctness in anatomical structure. Such fluctuations in the number, lumen size, wall thickness and cell type are presented in the WD profiles. 
The spruce profiles were more predictable and fairly similar compared with the birch samples and exhibited an S-shaped profile. Averaged over the entire spruce data set, the WD in the EW within the annual ring was $260 \pm 30 \mathrm{~kg} / \mathrm{m}^{3}$. Thereafter, the WD slightly increased with increasing distance from the growth ring boundary, and at a relative distance of approximately $60-70 \%$ of the total growth ring width, WD increased more rapidly until the end of the growth ring, where the current results show the same tendency as reported by Cuny et al. (2014). The WD of the LW was $940 \pm 160 \mathrm{~kg} / \mathrm{m}^{3}$, which was 3-3.5 times higher than that of the EW. As shown in Figure 5a, a cross-section of spruce wood consisted primarily of one type of cell: vertically oriented rectangular tracheids. Good correlations were observed between the WD profile and porosity within the annual ring of spruce samples. Sedighi-Gilani et al. (2014) found that the porosity of LW (27\%) is approximately 3 times lower than that of EW (76\%). The increased WD and porosity are thus primarily caused by cell wall thickening as well as by cell size reductions in the radial direction. Similarly, certain density profiles of spruce within the growth ring have two distinct peaks, known as "false rings" and related to climate and soil conditions (amount of precipitation and soil water reserves). Fritts (2001) and Bouriad et al. (2005) confirmed that the formation of LW-like cells can be triggered within EW during drought seasons, whereas EW-like cells may emerge in response to rainfall after the seasonal drought in late summer or early autumn and interrupt the formation of LW.

Compared with spruce, the transition periodicy from EW to LW in radial WD profiles in birch samples are less pronounced; and it was difficult to to distinguish LW from EW. These differences might have been caused by several substantial differences in anatomical features. As shown in Figure 5a, the anatomical structure of birch consists of various fibrous elements, with axial or vertical elements represented by vessels and libriform fibers, and radial or horizontal elements represented by ray parenchyma cells. Compared with spruce, birch has vessels, cells with large lumens and thin cell walls, explaining the lower amount of cell wall material. Birch is a semi-diffuse-porous wood species, and seasonal changes have little effect on the vessels. The vessels change slightly in size or distribution from EW to LW, and the average lumen diameter is approximately $50 \pm 20 \mu \mathrm{m}$. Therefore, abrupt changes within one growth ring from EW to LW were not observed. The porosity of EW is approximately $25 \%$ higher than that of LW, with values of $64 \%$ and $48 \%$, respectively. As previously mentioned, porosity is well correlated with density, and the average density of LW was $780 \pm 40 \mathrm{~kg} / \mathrm{m}^{3}$, which was $30 \%$ higher compared with that of EW. Hence, large 
271

272

273

reductions in density did not occur within the growth rings in birch as was observed for spruce.

\section{Changes in density profile induced by THT}

The relationship between the radial density profiles of both wood species and onestage heat treatment processing parameters is shown in Figure $4 \mathrm{a}$ and $4 \mathrm{~d}$. A slightly decreasing trend in the density profile occurred after treatment at $160^{\circ} \mathrm{C}$, and the curves of the treated samples have the same shape as those of untreated samples. As expected, with increasing treatment temperature, the WD profiles decrease with a maximum difference between the untreated and treated woods at $180^{\circ} \mathrm{C}$. The observed changes in radial density caused by the thermal treatment temperature can be explained by the higher shrinkage compared to weight loss.

From earlier results, most of the mass loss can be attributed to hemicelluloses and extractives, which have the highest susceptibility to thermal decomposition. During treatment, hemicellulose autohydrolysis (dehydration) occurred, and low molecular weight compounds (acetic acid, furfural and water) evaporated and were thus, removed from the cell wall during the cooling stage, which resulted in mass loss. Simultaneously, the free space between macromolecular constituents gradually decreased, and the matrix was rearranged, and as the distance between the macromolecules decreased, single cell walls were reduced in size. 3D renderings of the X-ray volumes of birch (Figure 5a) and spruce (Figure 5b) before and after treatment clearly illustrate this shrinkage; however, large alterations in the microstructure of the wood tissue after THT did not occur.

Due to the presence of latewood in spruce, the wood density profile was corrected according the shrinkage of spruce wood at applied treatment temperatures. As LW contains more wood matter, it has higher shrinkage values compared to EW. Therefore, the peaks of WD of treated spruce are shifted to the left. To avoid this drawback the profiles were linearly interpolated to have equal lengths. The expansion coefficient for treated spruce latewood at 160, 170 and 180 ${ }^{\circ} \mathrm{C}$ is 2,5 and $9 \%$ and for early wood it was $0.1,0.3$ and $0.5 \%$, respectively. 

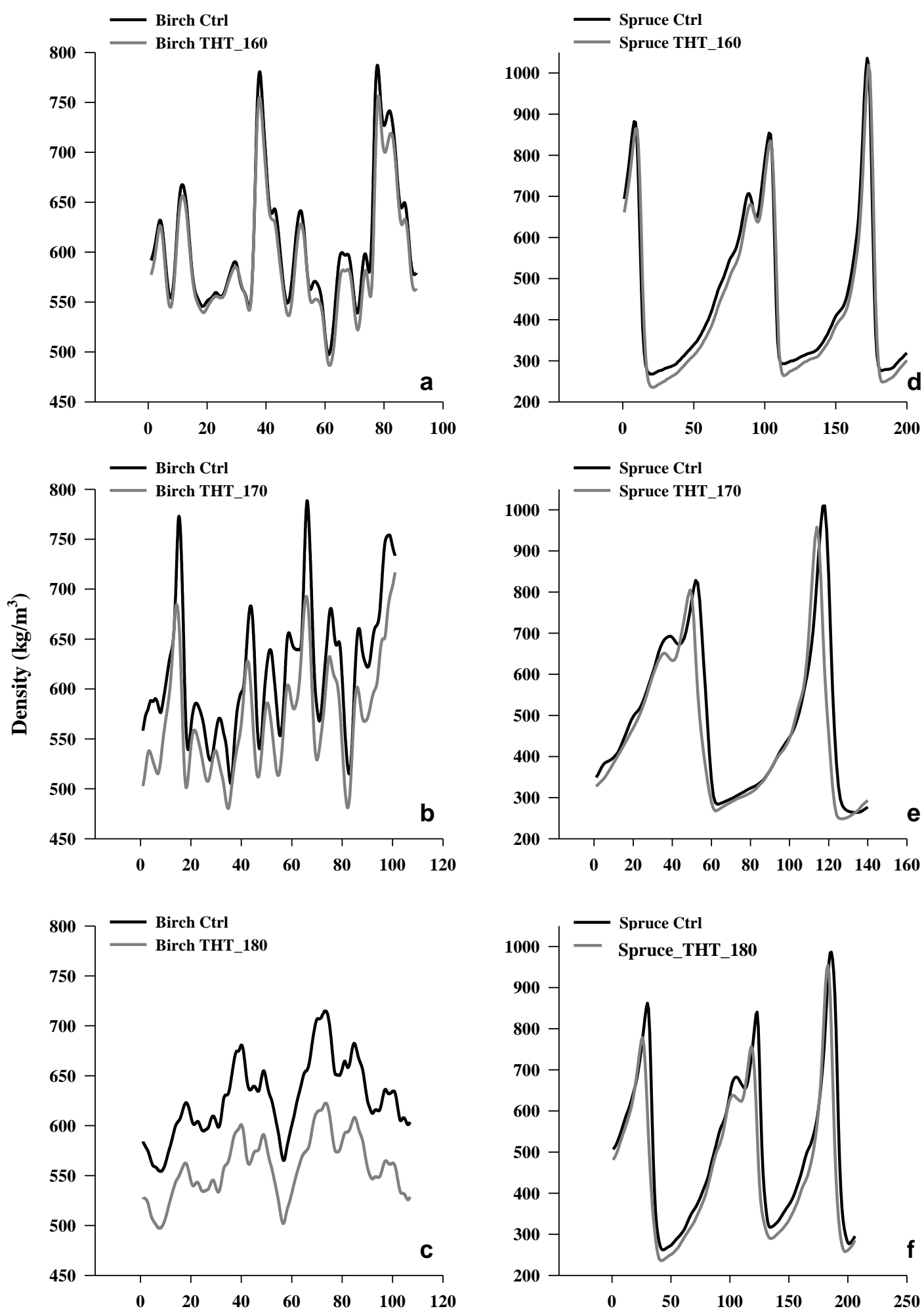

No. of slices

No. of slices

Figure 4. Impact of treatment temperature on the radial density profiles of birch (a, b, c) and spruce (d, e, f) treated at 160,170 and $180^{\circ} \mathrm{C}$. $*$ Slice thickness is $25 \mu \mathrm{m}$. 

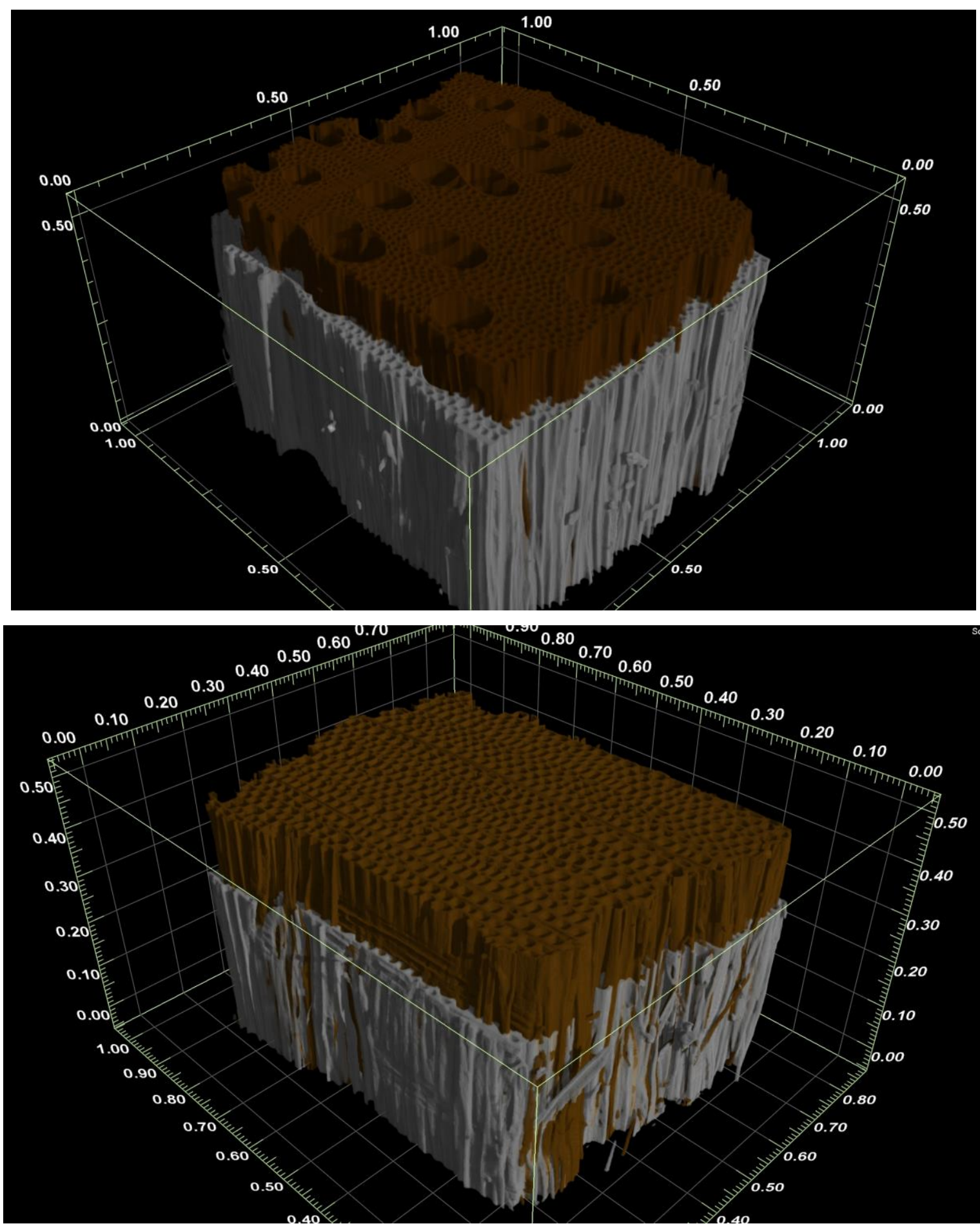

Figure 5. Shrinkage of (a) birch and (b) spruce samples after THT at $160^{\circ} \mathrm{C}$. Untreated samples are gray, and treated samples are more dark gray.

Changes in density of EW and LW by THT

As previously mentioned, changes in EW and LW caused by THT are difficult to observe; therefore, the distances between the density profiles of untreated versus treated 

samples were plotted (Figure $6 \mathrm{a}$ and $6 \mathrm{~b}$ ) to differentiate among the density changes in EW and LW within the growth ring caused by the thermal treatment. Therefore, to assess whether the EW has similar or different decreases in density compared to LW, the difference between the density profiles of untreated and treated samples were calculated and plotted as linear regression lines. Different alteration of microstructure of EW and LW caused by THT could be explained bydistances between radial density profiles of untreated and treated samples, or by linear regression plots. Decreases or increases in distance between radial density profiles of untreated and treated samples (non-parallel linear regression lines) give evidence of different impact of THT on the EW and LW. Figure 6a and 6b clearly confirm that a decrease in EW and LW density profiles did not differ for birch treated at the given temperatures, as proven by the parallel trend of the regression lines. However, the lines are not parallel for spruce. With increasing treatment temperature, the lower density values (EW) are reduced to a lesser degree compared with LW. It can be that these changes in the density profiles attributed to the difference in volumetric change of growth rings during thermal treatment. Quirk (1984) observed that the Douglas-fir EW lumen expanded and the LW lumen contracted during drying. Hence, with the evaporation of water and low molecular weight products from the tracheid material, the cell walls shrink and the lumen can shrink, expand or remain constant (Pang 2002) because of differences in the cell structure (shape and thickness) and microfibril angles. Nevertheless, with increasing treatment temperature, the woody matter decreases, and irreversible changes occur.
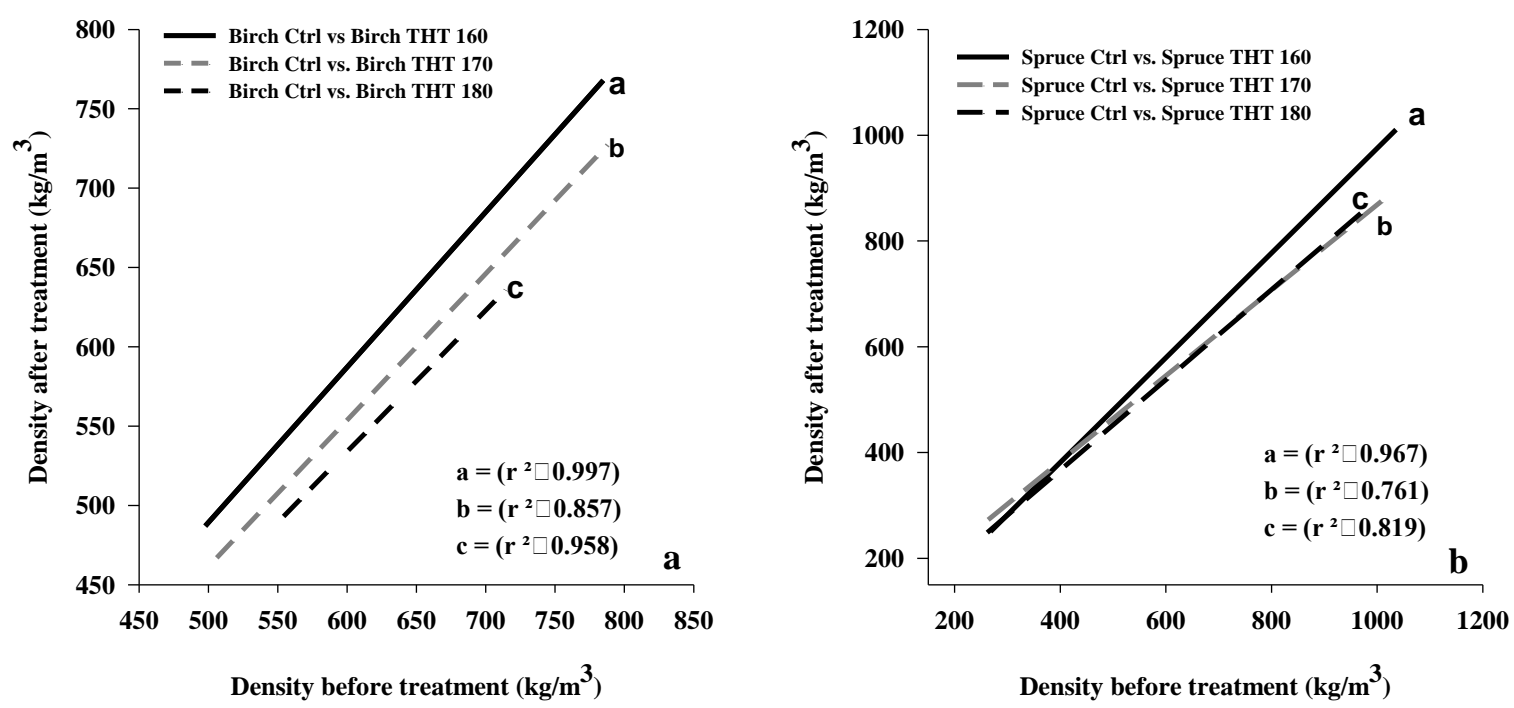
Figure 6. Impact of treatment temperature on the distances between radial density profiles of untreated and treated a) birch and b) spruce specimens compared by linear regression.

\section{Conclusion}

The use of X-ray CT coupled with image analysis provided an accurate method for studying changes in wood tissue caused by THT. The results show that with increasing treatment temperature, the density profiles decrease regardless of the wood species. Differences were observed between birch and spruce with respect to density changes in the EW and LW after THT, which clearly indicates that increased temperature has a specific effect on the density profile of spruce within the annual ring. Consequently, thermal behavior of wood species with defined arrangement of fibers within the growth ring (LW and EW) is subject to displacements of wood tissue, which differs in LW and EW. While previously density profile measurements have only been performed for non-treated wood, the work presented here shows that it is becoming possible to observe changes in density profiles induced by THT or due to other treatment processes using X-ray CT scanning.

\section{Acknowledgments}

This project is part of the U4 Network sponsored by the DAAD program "Strategic Partnership" and the Federal Ministry of Education and Research.

\section{References}

Altgen M, Willems W, Militz H (2016) Wood degradetion affected by process conditions during thermal modification of European beech in a high pressure reactor system. Eur. J Wood Prod. 74(5):653-662.

Biziks, V., Andersons, B., Sansonetti, E., Andersone, I., Militz, H., Grinins, J. (2015) Onestage thermos-hydro treatment (THT) of hardwoods: An analysis of form stability after five soaking-drying cycles. Holzforschung. 69(5):563-573.

Boone M, De Witte Y, Dierick M, Van den Bulcke J, Vlassenbroeck J, Van Hoorebeke L (2009) Practical use of the modified Bronnikov algorithm in micro-CT. Nucl. Instrum. Methods Phys. Res. Sect. B: Beam Interact. Mater. At. 267:1182-1186.

Boonstra, M.J., Van Acker, J., Tjeerdsma, B.F., Kegel, E.V. (2007) Strength properties of thermally modified softwoods and its relation to polymeric structural wood constituents. Ann. Sci. 64(7):679-690.

Bouriand, O., Leban, J.K., Bert, D., Deleuze, C. (2005) Intra-annual variations in climate influence growth and wood density of Norway spruce. Tree Physiol. 256(6):651-660.

Brabant L, Vlassenbroeck J, De Witte Y, Cnudde V, Boone MN, Dewanckele J, Van Hoorebeke L (2011) Three-dimensional analysis of high-resolution X-ray computed tomography data with Morpho+. Microsc. Microanal. 17:252-263. 
Clauder L, Schhupakivskyy R, Pfriem A (2014) Application of high-frequency densitometry to detect the change of early- and latewood density of Oak (Quercus Robur L.) due to thermal treatment. Proceeding of $8^{\text {th }}$ European Conference on Wood Modification. 5156.

Cuny EH, Rathgeber CBK, Frank D, Fonti P, Fournier M (2014) Kinetics of tracheid development, explain conifer tree-ring structure. New Phytol. 203(4):1231-1241.

De Ridder, M., Van den Bulcke, J., Vansteenkiste, D., Van Loo, D., Dierick, M., Masschaele, B., De Witte, Y., Mannes, D., Lehmann, E., Beeckman, H., Van Hoorebeke, L., Van Acker, J. (2011) High-resolution proxies for wood density variations in Terminalia superba. Ann. Bot. 107(2):293-302.

De Witte Y, Boone M, Vlassenbroeck J, Dierick M, Van Hoorebeke L (2009) Bronnikovaided correction for X-ray computed tomography. J. Opt. Soc. Am. A-Opt. Image Sci. Vis. 26:890-894.

Dierick M, Van Loo D, Masschaele B, Boone M, Van Hoorebeke L (2010) A LabVIEW® based generic CT scanner control software platform. J. X-ray Sci. Technol. 18:451461.

Dierick M, Van Loo D, Masschaele B, Van den Bulcke J, Van Acker J, Cnudde V, Van Hoorebeke L (2014) Recent scanner developments at UGCT Nucl. Instrum. Methods Phys. Res. Sect. B: Beam Interact. Mater. At. 324:35-40.

Dietrichs, H.H., Sinner, H., Puls, J. (1978) Potential of steaming hardwoods and straw for feed and food production. Holzforschung 32:193-199.

Freyburger C, Longuetaud F, Mothe F, Constant T, Leban JM (2009) Measuring wood density by means of X-ray computed tomography. Ann. Forest. Sci. 66:804 (p:19).Fritts, H.C. (2001) Tree rings and climate. The Blackburn Press. London.

Gilmore AR, Metcalf GE, Boggess WR (1959) Specific gravity of shortleafe pine and loblolly pine in southern Iillionois. J. For. 59: 894-896.

González-Peña MM, Curling SF, Hale MDC (2009) On the effect of heat on the chemical composition and dimensions of thermally-modified wood. Polym.Degrad. Stabil. 94:2184-2193.

Grinins, J., Andersons, B., Biziks, V., Andersone, I., Dobele, G. (2013) Analytical pyrolysis as an instrument to study the chemical transformations of hydrothermally modified wood. J. Anal. Appl. Pyrol. 103:36-41.

Guilley E, Herve JC, Nepveu G (2004) The influence of site quality, silviculture and region on wood density mixed model in Quercus petraea Liebl. For. Ecol. Manage. 189: 111121.

Hamada J, Pétrissans A, Mothe F, Pétrissans M, Gerardin P (2017) Intraspecific variation of European oak wood thermal stability according to radial position. Wood Sci. Technol. 51:785-794.

Izekor DN, Fuwape JA, Oluyege AO (2010) Effects of density on variations in the mechanical properties of plantation grown Tectona grandis wood. Archives of Applied Sci. Res. 2(6): 113-120.

Klüppel A, Mai C (2013) The influence of curing conditions on the chemical distribution in wood modified with thermosetting resins. Wood Sci. Technol. 47:643-658.

Lindgren LO (1991) The accuracy of medical CAT-scan images for non-destructive density measurements in small volume elements within solid wood. Wood Sci. Technol. 25:425-432.

Mantanis GI, Young RA, Rowell RM (1994) Part I. Swelling of wood. Wood Sci. Technol. 28:119-134. 
Meincken M, du Plessis A (2013) Visualising and quantifying thermal degradation of wood by computed tomography. Eur. J. Wood Prod.71:387-389.

Mull RT (1984). Mass estimates by computed tomography: physical density from CT numbers. Am. J. Roentgenol. 143: 1101-1104.

Niemz, P. (1993) Physik des Holzes und der Holzwerkstoffe. DRN-verlang, Lernfeldern Echterdingen.

Pang S (2002) Predicting anisotropic shrinkage of soft wood. Part 1: Theories. Wood Sci. Technol. 36: 75-91.

Pfriem A, Clauder L, Linke N, Schhupakivskyy R (2014) Application of high-frequency densitometry to detect the change of early- and latewood density of Oak (Quercus Robur L.) due to thermal treatment. Proceeding of $7^{\text {th }}$ European Conference on Wood Modification.

Rathgeber CBK, Decoux V, Leban JM (2006) Linking intra-tree ring wood density variations and tracheid anatomical characteristics in Douglas fir (Pseudotsuga menziesii (Mirb.) Franco). Ann. For. Sci. 63:699-706.

Rautkari L, Kutnar A, Hughes M, Kamke F (2010) Wood surface densification using different methods. Wood conference in timber engineering.

Sedighi-Gilani, M., Boone, N.M., Mader, K., Schwarze, F.W.M.R. (2014) Synchotron X-ray mocro-tomography imaging and analysis of wood degraded by Physisporinus vitreus and Xylaria longipes. J. Struct. Biol. 187:149-157.

Steffenrem A, Kvaalen H, Sigm K, Høibø D, Høibø O (2014) A high throughput X-ray based method for measurements of relative wood density from unprepared increment cores from Piceas abies. Scand. J. Forest. Res. 29(5): 506-514.

Quirk JT (1984) Shrinkage and related properties of Douglas-fir cell walls. Wood Fiber Sci. 16: $115-133$.

Vlassenbroeck J, Dierick M, Masschaele B, Cnudde V, Van Hoorebeke L, Jacobs P (2007) Software tools for quantification of X-ray microtomography at the UGCT. Nucl. Instrum. Meth. Phys. Res. A. 580:442-445.

Wong AHH, Wilkes, J, Heather WA (1983). Influence of Wood Density and Extractive Content on the Decay of the Heartwood of Eucalyptus delegatensis R.T. Baker. J. Inst. Wood Sci.54: 261-263

Yildiz S, Gezer D, Yildiz U (2006) Mechanical and chemical behavior of spruce wood modified by heat. Building. Environ. 41:1762-1766. 